УДК $2-1 ; 2 ; 2-3 ; 224.5$

\title{
ЛИЧНОСТЬ ПРОРОКА ДАНИИЛА В КОНТЕКСТЕ БИБЛЕЙСКОЙ ИСТОРИИ
}

\section{Плохий Евгений Викторович}

слушатель

Религиозная организация - духовная образовательная организация высшего образования

Белгородская Православная Духовная семинария (с миссионерской направленностью)

Православной религиозной организации

Белгородской и Старооскольской епархии

Русской Православной Церкви Московского Патриархата

Аннотация: В научной статье автором рассмотрены и проанализированы существенные периоды формирования личности святого пророка Даниила в контексте библейской истории. Также автором научно - исследовательской работы обоснована и показана особая актуальность и значение личности святого пророка Даниила и его Книги, как для православного богословия, так и для жизни каждого современного человека.

Ключевые слова: философия, православное богословие, библеистика, Ветхий Завет, Книга пророка Даниила, личность, пророчество.

\section{THE PERSONALITY OF THE PROPHET DANIEL IN THE CONTEXT OF BIBLICAL HISTORY}

\section{Plokhii Yevgenii Viktorovich}

\begin{abstract}
In the scientific article, the author considers and analyzes the significant periods of the formation of the personality of the holy prophet Daniel in the context of biblical history. Also, the author of the research work substantiates and shows the special relevance and significance of the personality of the holy Prophet Daniel and his Book, both for Orthodox theology and for the life of every modern person.
\end{abstract}

Key words: philosophy, Orthodox theology, biblical studies, the Old Testament, the Book of the prophet Daniel, personality, prophecy. 
Книга пророка Даниила занимает важное место среди канонических пророческих книг Ветхого Завета [1]. Личность святого пророка Даниила незаурядна и значима не только для своей эпохи, но и для современного человека, поскольку является примером и образцом преданности и любви к Богу.

Пророчество как особенный дар от Бога, было дано святому пророку Даниилу для того, чтобы возвещать будущее, и являться видимым доказательством его истинной связи с Богом. По мнению Филона

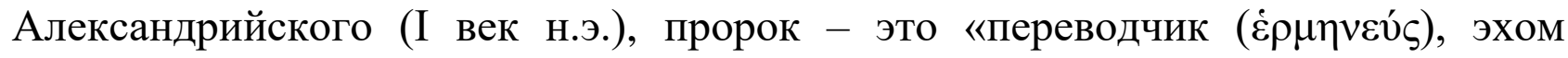
изнутри отзывающийся на речения Бога, от Бога же не исходит ничего ошибочного» [2, с. 25].

Несмотря на то, что «служение пророков или апостолов всегда обусловлено призванием свыше» [3, с. 10], пророк остаётся человеком, и как человек, призванный Богом к особому виду служения, он должен обладать определённым героизмом и мужеством, чтобы не устрашиться сообщить людям то, что открыто ему Богом.

Одним из тех, кто, несомненно, обладает данным качеством, является великий ветхозаветный пророк Даниил. Святой пророк Даниил жил в VI веке до Рождества Христова и упоминается в числе еврейских юношей, уведённых вавилонским царём Навуходоносором в плен.

С.А. Песоцкий в книге «Святой пророк Даниил, его время, жизнь и деятельность» пишет о святом Данииле: «светлая личность его настолько заметно выделяется в виду истории богоизбранного народа, что привлекает к себе особенное внимание» [4].

А.П. Лопухин отмечает, что «со стороны своего содержания книга пророка Даниила разделяется на две части: историческую (главы 1 - 6) и пророческую (главы 7 - 12)» [5, с. 13]. В исторической части содержатся данные о жизни пророка Даниила и совершающихся событиях времён Вавилонского царства и Мидо-Персии, то есть VI - IV веках до н.э. Пророческая часть Книги пророка Даниила отображает откровения, полученные святым пророком Даниилом [6].

Для выявления более точной датировки написания книги пророка Даниила проводилось немалое количество исследований, базировавшихся на разных основаниях, разной направленности, в том числе, и библейско богословских. Проведя некоторую их систематизацию, можно сформулировать следующие положения, касающиеся установления или определения датировки 
написания книги пророка Даниила. В частности, С.А. Песоцкий на основании своего библейско - богословского исследования, приводит важные данные для выявления датировки Книги пророка Даниила. В частности, он указывает на то, что Книга пророка Даниила написана именно в период вавилонского пленения, о чём свидетельствуют прежде всего языки, на которых эта книга написана.

Книга Даниилова написана на нескольких языках: «еврейский $1-2: 3$ и $8-12$ главы и арамейский 2:4 - 7:28 главы». А.П. Лопухин указывает на то, что пророк Даниил «как иудей по происхождению, ... знает свой родной язык, а как вавилонянин по местожительству - общенародный в Вавилоне арамейский» язык [7, с. 5]; а также главы 13 и 14, которые отсутствуют в еврейском тексте и дошли до нас только на греческом языке [8, с. 102].

Написание Книги пророка Даниила некоторые протестантские исследователи относят к середине II века до н. э. (эллинистический период), однако с таким утверждением не соглашается большинство православных ученых, поскольку оно отрицает сам факт пророчеств, провозглашенных Святым Даниилом.

В свою очередь, научный мир не ставит под сомнение тот факт, что найденные тексты Кумранской общины, в том числе, связаны и с Книгой пророка Даниила: «Среди рукописных отрывков, найденных в пещерах Кумрана, значительное число составляют фрагменты ветхозаветных книг, в ряде случаев, переписанных во многих экземплярах. ... книги 12 пророков восемью фрагментированными экземплярами» [9, с. 80]. На ту же тему пишут и некоторые другие современные исследователи: «древнейшие фрагменты рукописей Книги Даниила, дошедшие до наших дней, принадлежат библиотеке Кумранской общины (они найдены в числе «свитков Мертвого моря» в пещерах Иудейской пустыни) и относятся ко II веку до н. э. К этому времени Книга Даниила была общеизвестна и глубоко почитаема в Иудее и уже имела долгую историю своего распространения и изучения» [10, с. 6].

О пророке Данииле свидетельствует его современник, живший в VI веке до н.э., и тоже уведённый в вавилонский плен - пророк Иезекииль. В своей пророческой книге он упоминает святого Даниила вместе с праведными Ноем и Иовом, которые тоже жили среди язычества и нечестия, что, однако, не помешало им сохранить свою праведность: «И было ко мне слово Господне: сын человеческий! если бы какая земля согрешила предо Мною, вероломно отступив от Меня, и Я простер на нее руку Мою, и истребил в ней хлебную опору, $и$ послал на нее голод, и стал губить на ней людей и скот; и если бы нашлись в 
ней сии три мужа: Ной, Даниил и Иов, - то они праведностью своею спасли бы только свои души, говорит Господь Бог» (Иез. 14, 12-14).

Святой пророк Даниил - потомок знатных иудеев (из колена Иудина), уведённый в юношеском возрасте в вавилонский плен в период завоевания царём Навуходоносором Иерусалима (около 606 - 607 годы до Рождества Христова) (Дан. 1, 3-6).

Будущий пророк вместе со своими ближайшими друзьями Ананией, Азарией и Мисаилом был забран на воспитание при царском дворе (Дан. 1, 4, 17 - 18). Навуходоносор приказал выбрать лучших представителей иудейской молодёжи. Главную цель царь видел в том, чтобы «научить их книгам и языку халдейскому» (Дан. 1, 4). Этих особо обученных молодых людей в будущем ждали ответственные административные посты при царском дворе. К юношам, предназначенным для такой роли, предъявлялся ряд определённых, довольно строгих требований - это должны были быть «отроки, у которых нет никакого телесного недостатка, красивые видом, и понятливые для всякой науки» (Дан. $1,4)$. Юношей обучили языку и литературе Вавилона, а также математике, мореплаванию, политике, истории и географии. Вместе с тем для них предназначался особый рацион питания: «назначил иарь им ежедневную пищу $c$ царского стола и вино, которое сам пил» (Дан. 1, 5).

Возникает вопрос о той цели, которую преследовал вавилонский Царь Навуходоносор, приводя в свой дворец молодёжь из знатных родов, завоёванных им народов и предоставляя им прекрасные условия для жизни, обучения и последующей государственной карьеры. Царь таким образом, решил «провести некоторую «инкультурацию» евреев» [11], взятых в плен, в свою культуру - халдейскую. Это в очередной раз напоминает нам о том, что «пространство культурного взаимообогащения очень велико» [12, с. 56]. Именно для того выбирались дети самых знатных еврейских родов, чтобы они в будущем, получив соответствующее образование, перевоспитались на халдейский лад. То есть, предполагалось вырастить из них людей лояльных к вавилонским правителям, и в дальнейшем «они уже должны были осуществлять управленческие функции в своём народе» [13].

Очевидно, что дети или юноши подходили для этого лучше всего. Потому что дети более подвержены внутренним изменениям, чем взрослые, уже утвердившиеся в своих идеалах. Именно по этой причине, важно быть рядом со своими детьми, и не отпускать их «на воспитание улице», а образовывать душу ребёнка, насаждая в ней евангельские идеи, подавая пример, прежде всего, своей собственной жизнью. Поскольку для человека именно семья является самым главным училищем благочестия и стяжания добродетелей. 
В труде «Беседы на Шестоднев» святитель Василий Великий пишет об особых свойствах души, развитие, которых является первым этапом на пути к приобретению духовно - нравственного прохождения своего жизненного пути, так как «без духовно - нравственного преображения, совершенствования и бытия человека невозможно правильное понимание и толкование Священного Писания, поскольку основное видение очами духовными доступно только христианам» [14, с. 145]. Святитель Василий Великий объясняет, что никакое научное знание не обучает нас ненависти к телесным недугам, но по устройству души, созданной по образу Божию, мы имеем в себе неприязнь ко всякой причине, приносящей нам скорбь. Так и в душе нашей мы имеем некоторое естественное ей качество, усвоенное не научением, уклоняться от зла, поскольку именно «свобода выбора между добром и злом качественно характеризует личность» [15, с. 24].

В любой, даже самой сложной ситуации, пророк Даниил не поступался своими жизненными принципами и не разменял свою преданность Богу на личные блага. Так, например, пост занимал особое место в жизни пророка Даниила. Именно пост предшествовал толкованию пророком Даниилом сна Навуходоносора об истукане (Дан. 2, 26 - 46). Также перед явлением ему Архангела Гавриила пророк Даниил постился (Дан. 8, 16; 9, 21).

Перед другим важным откровением пророк Даниил наложил на себя строгий трехнедельный пост: «B эти дни я, Даниил, был в сетовании три седмиџы дней. Вкусного хлеба я не ел; мясо, и вино не входило в уста мои, и мастями я не умащал себя до исполнения трёх седмиц дней» (Дан. 10, 2 - 3).

Следовательно, множество Библейских событий или прошений были предварены постом. Сам Господь перед своим служением миру 40 дней находился в пустыне в посте (Мф. 4, 1 - 2). Можно упомянуть и другие факты героизма святого пророка Даниила, характеризующие его как выдающуюся личность: это и сидение во рву с голодными львами (Дан. 14, 30 - 32), и мужественное возвещение воли Бога царям Навуходоносору (Дан. 4, 24) и Вальтасару (Дан. 5, 17 - 28), а также чистота сердца расположенного к видению по воле Бога будущего (Дан. 7, 2 - 28).

Подводя итоги, необходимо ещё раз отметить, что личность святого пророка Даниила в контексте библейской истории по-своему абсолютно уникальна и значима. Весь путь служения Богу святого пророка Даниила - это подвиг пророческого служения, которое направлено непосредственно от Бога одновременно ко всем людям, и к каждому конкретному человеку. 


\section{Список литературы}

1. Библия. - Москва: Российское Библейское Общество, 2020. - 1337 с.

2. Вевюрко И.С. Пророческое вдохновение в Ветхом Завете: древнейшая интерпретация в свете современных исследований // Философия религии: аналитические исследования. - Москва, 2018. - Т. 2. - № 2. - С. 25 - 50.

3. Куренков А., прот. Пастырское служение: проблемы призвания и профессионального «выгорания» священнослужителя. // Труды Белгородской духовной семинарии (с миссионерской направленностью). Выпуск VI: Сборник научных трудов. / По благословению Высокопреосвященнейшего ИОАННА, Митрополита Белгородского и Старооскольского. - Белгород: Изд - во «СКпресс», 2017. - Вып. VI. - С. 9 - 13.

4. Песоцкий С.А. Святой пророк Даниил, его время, жизнь и деятельность. [Электронный ресурс] - URL: https://azbyka.ru/otechnik/ Zhitija_svjatykh/svjatoj-prorok-daniil-ego-vremja-zhizn-i-dejatelnost/ (дата обращения: 18. 04. 2021).

5. Толковая Библия, или Комментарии на все книги Св. Писания Ветхого и Нового Завета под редакцией А.П. Лопухина: В 7 - ми томах. Том V: Пророческие книги. Изд. 4 - е. - Москва: Изд - во «ДАРЪ», 2009. - 992 с.

6. Песоцкий С.А. Святой пророк Даниил, его время, жизнь и деятельность. [Электронный ресурс] - URL: https://azbyka.ru/otechnik/Zhitija_ svjatykh/svjatoj-prorok-daniil-ego-vremja-zhizn-i-dejatelnost/ (дата обращения: 18. 04. 2021).

7. Толковая Библия, или Комментарии на все книги Св. Писания Ветхого и Нового Завета под редакцией А.П. Лопухина: В 7 - ми томах. Том V: Пророческие книги. Изд. 4 - е. - Москва: Изд - во «ДАРЪ», 2009. - 992 с.

8. Толковая Библия, или Комментарии на все книги Св. Писания Ветхого и Нового Завета под редакцией А.П. Лопухина: В 7 - ми томах. Том V: Пророческие книги. Изд. 4 - е. - Москва: Изд - во «ДАРЬ», 2009. - 992 с.

9. Амусин И.Д. Рукописи Мёртвого Моря. / Отв. редактор профессор М.И. Ковалёв. - М.: Изд - во Академии Наук СССР, 1960. - 272 с.

10. Щедровицкий Д.В. Пророчества Книги Даниила. 597 год до н.э. -2240 год н.э. - 3 - е изд., стер. - Москва: Изд - во «Оклик», 2010. - 278 с.

11. Сысоев Д., иерей. Толкование книги пророка Даниила. [Электронный pecypc] - URL: https://azbyka.ru/otechnik/Daniil_Sysoev/tolkovanie-knigi-prorokadaniila/ (дата обращения: 18. 04. 2021). 
12. Рубежанский С.И. Диалога культур, как явление человеческой экзистенции. // В сборнике: Вопросы развития филологии и литературы в России и мире. Современная литература и культурные традиции. / Материалы II Всероссийской научной Интернет - конференции с международным участием. Сервис виртуальных конференций Pax Grid; ИП Синяев Д.Н. Казань: Издательство «Индивидуальный предприниматель Синяев Дмитрий Николаевич (Казань)», 20 мая 2014 года. - С. 55 - 57.

13. Сысоев Д., иерей. Толкование книги пророка Даниила. [Электронный pecypc] - URL: https://azbyka.ru/otechnik/Daniil_Sysoev/tolkovanie-knigi-prorokadaniila/ (дата обращения: 18. 04. 2021).

14. Неганов В.В. Основные тенденции развития философских и богословских взглядов на допустимые методы толкования Священного Писания в экзегетике каппадокийских Отцов Церкви (святитель Василий Великий). // Вестник Московского государственного областного университета. Серия: Философские науки. - Москва: Изд - во МГОУ, 2018. - № 3.-С.139-149.

15. Байдакова М.Ю. Проблема воли в философии и христианской антропологии: автореферат дис. ... кандидата философских наук: 09.00.01. Москва, 2008. - 26 с.

(c) Е.В. Плохий, 2021. 